\title{
Telecommunication Tower Retribution Contribution Against the Original Regional Income of Kulonprogo Regency (2015-2019)
}

Fikri Budi Aulia, S.E, M.M

Faculty of Economics and Business

Janabadra University

Yogyakarta, Indonesia

fikri.aulia@janabadra.ac.id

Sungkono, S,E., MSi.Ak, CA

Janabadra University

Yogyakarta, Indonesia

sungkono@janabadra.ac.id
Nurwiyanta, S.E, M.M

Faculty of Economics and Business

Janabadra University

Yogyakarta, Indonesia

nurwiyanta@gmail.com

Dra. Kartinah, M.Si.

Faculty of Economics and Business

Janabadra University

Yogyakarta, Indonesia

kartinah@janabadra.ac.id

the transfer of a number of authorities (affairs) from the central government to the relevant regional governments. The transfer of various powers in the framework of decentralization must of course be accompanied by the transfer and transfer of financing. The most important source of financing is a source of financing known as Regional Original Income (PAD), where the main component is revenue derived from local taxes and levies. Regional Autonomy is regional empowerment in making regional decisions more freely to manage their resources according to the potential and interests of the region itself. With wide, real, responsible regional autonomy, each region is required to increase its independence. One of the benchmarks to see regional readiness is to measure how much the regional financial capacity is to carry out regional autonomy. One of the sources of finance comes from the original regional income.

In order to improve regional financial capacity in order to implement autonomy, the government has implemented various taxation policies amending Law No. 18 of 1997 concerning Regional Taxes and Regional Levies. It is hoped that the granting of authority in the imposition of regional taxes and levies can further encourage the Regional Government to continue to strive to optimize Regional Original Revenue, especially those derived from regional taxes and levies.

From the original regional income sources, one of the sources that has a high enough potential is regional retribution. Regional levies are revenues obtained from sources within their own territory which are collected based on regional regulations and in accordance with applicable laws and regulations. The financing of 
regional expenditures in carrying out government and development tasks results in the collection of various types of regional levies related to various aspects of community life. [1]

Law Number 34 Year 2000 regarding Regional Taxes and Regional Levies, Article 18 paragraph 2 concerning the determination of the types / categories of charges stipulates that regional levies fall into three categories, namely public service levies, business service levies, and certain licensing fees. [2] One of the alternatives to regional retribution that contributes and can increase local revenue (PAD) is telecommunication tower charges.

Telecommunication tower levies are payments for the use of space and land in a regency / municipality. Along with the increasing activity of cellular telecommunication users, the people of Kulon Progo Regency have encouraged telecommunication service owners and providers to build new telecommunication towers to support their services. Increasing the number of telecommunication towers erected, the Government issued several regulations to regulate the construction of telecommunication towers in Kulon Progo Regency.

The construction of the new tower will utilize space and land in an area. This has a quite serious impact, where the construction of an unorganized tower will reduce open land and reduce the aesthetic value of the spatial layout of an area. The construction of this unorganized tower at its downstream will bring new problems, namely conflicts between the community and the tower owner.

The problems that occur as mentioned above, make policy makers, in this case the district / city government, become a dilemma. Two different sides must be walked right, namely on the one hand the local government must fulfilling the need for telecommunications services for the entire population, on the other hand, it must control the development of telecommunications facilities (towers) by paying attention to spatial planning.

Based on these conditions, the central government finally issued a regulation on tower construction, namely the Minister of Communication and Information Technology Regulation Number 2 of 2008 concerning the Construction and Use of Joint Telecommunication Towers. As well as the passing of the Joint Ministerial Regulation (SKB) 3 Ministers and 1 Head of Agency, namely the Minister of Home Affairs, Minister of Public Works, Minister of Communication and Information and the Head of the Investment Coordinating Board Number 18 of 2009, Number 07 / PRT / M / 2009, Number 19 / PER / M.KOMINFO / 3/2009, and Number 3 / P / 2009 concerning Guidelines for the Construction and Joint Use of Telecommunication Towers have become legal instruments for the Central and Regional Governments to initiate the creation of a comprehensive Telecommunication Tower arrangement, both from the aesthetic and urban planning aspects, security, environment and protection for certain strategic areas.
The objectives of the Ministry of Communication and Information Regulation Number 2 of 2008 and the Joint Ministerial Regulation of 3 Ministers and 1 Head of Agency are to harmonize and synergize the division of affairs between the central government and local governments to regulate telecommunication joint towers. This joint decree also aims to prevent the provision of towers from monopolistic practices and unfair business competition among telecommunications industry players.

In this Joint Ministerial Regulation of 3 Ministers and 1 Head of Agency it is stated that the policy for joint telecommunication tower construction has an impact on several works that must be completed. The work includes the Regional Government to make a Perda on joint towers referring to the Joint Ministerial Regulation and accommodating local specifications and local wisdom. Regional governments are also asked to facilitate IMB licensing for joint towers, but are firm in enforcing the law through perda.

In addition, in 2009, Law Number 28 of 2009 concerning Regional Taxes and Regional Levies was promulgated which became a momentum for changes in public service levies, especially regarding Telecommunication Tower Control Levies, which the calculation of rates and amounts is based on the element of the building's tax object sale value (NJOP). telecommunication towers as mentioned in Article 110, Article 124 and the Elucidation of Article 124.

In May 2015, the Decision of the Constitutional Court Number 46 / PUU-XII / 2014 regarding Telecommunication Tower Control Charges was passed which stated that the Elucidation of Article 124 of Law Number 28 of 2009 concerning Regional Taxes and Regional Levies has no legal force so that it is no longer binding. This decision also changed the sentence phrase to become: "the determination of levy rates is based on the cost of monitoring and controlling telecommunications towers". Therefore the cost of supervision and control (wasdal) then uses a calculation formula which includes the following components: honorarium for supervisory officers, transportation, food allowance, office stationery. And if needed, of course, other relevant and demonstrable cost components can be added, such as capital costs and maintenance costs as regulated in articles 151,152 and 161 of the PDRD Law Number 28 of 2009.

With the enactment of this policy and an increase in the number of telecommunication towers that utilize space and land in Kulon Progo Regency, it will automatically increase the revenue / income of the Kulon Progo Regency Government from receiving Telecommunication Tower Retribution which affects the Regional Original Revenue.

This research will try to prove empirically whether the contribution of telecommunication tower levies to the local revenue of Kulonprogo Regency. 
Formulation of the Problem

How is the revenue growth, effectiveness level, and telecommunication tower charges in Kulon Progo Regency?

\section{LITERATURE REVIEW}

Regional Automomy

According to Law Number 32 Year 2004 concerning Regional Autonomous Regional Government, it is: "The right of authority and obligations of the autonomous region to regulate and manage government affairs and the interests of the local community in accordance with statutory regulations"

Autonomous regions according to Law Number 32 Year 2004 concerning Regional Government are: "Legal community units that have territorial boundaries which are authorized to regulate and administer government affairs and the interests of local communities according to their own initiative based on the aspirations of the people in the system of the Unitary State of the Republic of Indonesia"

The purpose of regional autonomy according to Law Number 32 of 2004 is that regional autonomy is directed at accelerating the realization of community welfare through improving services, empowerment and community participation, as well as increasing regional competitiveness by taking into account the principles of democracy, equity, justice, privileges and specificities of a regions in the system of the Republic of Indonesia. [3]

The target of regional autonomy is a level II region that knows better about the feelings, aspirations, potentials and problems faced by the community

The principles of granting regional autonomy according to Law Number 32 of 2004 are: Autonomy as widely as possible, real and responsible. As broad as possible, it means that the regions are given the authority to manage and regulate all government affairs outside of those of the Government which are stipulated in law, namely the fields of foreign policy, defense and security, justice, national fiscal, monetary and religion. It means that the regions have the potential to realize the contents and types of autonomy that are delegated. Responsible means autonomy which in its implementation must be strictly in line with the aims and purposes of granting autonomy. [4]

The implementation of autonomy which is oriented towards improving the welfare of the people, ensuring harmonious relations between regions and ensuring harmonious relations between regions and the government.

The benchmark for the implementation of regional autonomy is Regional Original Income (PAD). Where the ability of regional autonomy is measured by the ability to increase Regional Original Income (PAD).
Regional Revenue

Regional revenues based on Law No. 33 of 2004 concerning Financial Balance between Central and Regional Government are money that goes to the regional treasury

Sources of regional revenue based on Law no. 33 of 2004 article 5 consists of:

Indicators for the Success of Regional Autonomy Each level II region is able to manage its own household, all government affairs based on established criteria and worthy of submission to level II regions have been implemented

Regulatory instruments in the form of Government Regulations on assignment of functions have been reviewed and aligned with the nuances of development directed by GBHN. Original Regional Revenue which increases to support in a balanced manner according to need and allows for regional economic growth.

Regional revenue is the right of the regional government which is recognized as an addition to the value of net assets in the period in which the regional income comes from:

Original regional income is revenue obtained by a region from sources within its territory which is collected based on regional regulations in accordance with the prevailing laws and regulations.

Balancing funds are funds sourced from APBN revenues allocated to regions to finance regional needs in the context of implementing decentralization. The balance fund consists of:

\section{Profit sharing funds}

Profit sharing funds are funds sourced from APBN revenues allocated to regions based on percentage figures to finance regional needs in the context of implementing decentralization.

\section{General Allocation Fund (DAU)}

General allocation funds are funds sourced from APBN revenues which are allocated to regions with the aim of equal distribution of inter-regional financial capacity to finance regional needs in the context of implementing decentralization.

\section{Special Allocation Fund (DAK)}

Special allocation funds are funds sourced from APBN revenues allocated to certain regions with the aim of helping finance special activities which are regional affairs and in accordance with national priorities.

\section{Retribution}

Levies, hereinafter referred to as Retribution, are regional levies as payment for services or the granting of certain permits specifically provided and / or given by the 
Regional Government for the benefit of private persons or Entities.

Services are activities of the Regional Government in the form of businesses and services that cause goods, facilities or other benefits that can be enjoyed by private persons or Entities. Public Services are services provided or provided by the Regional Government for the purpose of public interest and benefit and can be enjoyed by private persons or Entities.

Business services are services provided by local governments adhering to commercial principles because in principle they can also be provided by the private sector.

Certain Permits are certain activities of the Regional Government in the framework of granting permits to private persons or other entities. Legitimate revenue is revenue from the central government and / or from central agencies, as well as from other regions. Other revenues consist of grant revenue, emergency funds, revenue sharing funds from the province and other local governments, funds adjustment and special autonomy as well as financial assistance funds from the province or other regional governments are intended for fostering, regulating, controlling and supervising activities, space utilization, and the use of natural resources, goods, infrastructure, facilities or certain facilities in order to protect public interests and preserve sustainability. environment. Retribution obliged is an individual or entity which, according to the statutory regulations, a levy is obliged to pay levies, including collecting or cutting certain levies

Retribution Period is a certain period of time which is the time limit for the Payer of Retribution to utilize certain services and licenses from the relevant Regional Government.

Regional Levy Deposit, hereinafter abbreviated as SSRD, is proof of payment or deposit of levies that have been made using forms or have been made by other means to the regional treasury through a payment place designated by the Regional Head.

Regional Retribution Decree, hereinafter abbreviated as SKRD, is a levy stipulation letter that determines the amount of the principal amount of levies payable.

An overpaying regional levy stipulation, hereinafter abbreviated as SKRDLB, is a levy determination letter that determines the amount of levy overpayment because the amount of levy credit is greater than the levy owed or should not be owed Regional Levy Bill, hereinafter abbreviated as STRD, is a letter to collect levies and / or administrative sanctions in the form of interest and / or fines.

Financial management

Financial management is a way of regarding an organization's ability to solve its financial problems, which include cash problems, budget problems, longterm obligations, and service problems (Wang, Dennis, and Tu 2007). According to Law No. 23/2014 Regional Financial Management (management) is all activities that include planning, implementation, administration, reporting, accountability and supervision of regional finances. Financial conditions indicate health which greatly affects the movement of government organizations in carrying out predetermined work programs. This is a consequence of implementing work programs that always require funds. Regional autonomy allows local governments to explore the financial potential of their respective regions and has great authority in managing finances. Good financial health enables local governments to carry out their work programs well as well.

Ritonga, Clark, and Wickremasinghe (2012) try to conceptualize the definition of sound financial management of local government in Indonesia. The concept includes the assessment of local government financial conditions, namely: short-term solvency, budgetary solvency, long-term solvency, financial flexibility, financial independence, and service level solvency. Thus, the definition of financial conditions in local government according to Ritonga, Clark, and Wickremasinghe (2012) is the financial capacity of local governments to meet their obligations, to anticipate unexpected events, and to use funds effectively and efficiently. The ratios to assess the financial condition of local governments are based on the information presented in the financial reports of local governments which are prepared based on government accounting standards. Local governments in Indonesia are required to use government accounting standards as stipulated in Government Regulation No. 71/2010. [3]

Its activities include:

1. Efforts and activities in order to increase company value (Government)

2. Efforts to get funds in the most profitable way and allocate funds efficiently within the company (government) as a means of achieving targets for shareholder wealth (local government)

H1: the development of telecommunication tower levy receipts is significant to the Regional Original Revenue in Kulon Progo Regency in 2015 to 2019

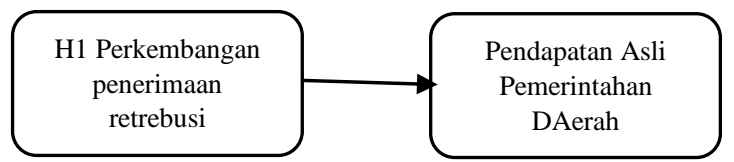

Figure 1: Framework

\section{RESEARCH METHODS}

\section{A. Type of Research}

This type of research is a case study. A case study is a type of research on a certain object by taking certain data and a certain time, the result is a complete picture and data collection is based on the object of research, the 
results only apply to the object under study and the conclusions cannot be generalized. This type of research is carried out at local government agencies regarding telecommunication tower charges received by the Kulon Progo Regency Government for the period of the 2015 fiscal year to the 2019 fiscal year

B. Time and Place of Research

1. Research Place: This research was conducted at the Department of Transportation, Communication and Information, Kulon Progo Regency

2. Research Time: July 2020 to November 2020

\section{Subjects and Objects of Research}

1. The subjects in this study are the agencies in charge of the collection of telecommunication tower levies in the Communication and Information Sector at the Department of Communication, Communication and Information Technology.

2. The object of this research is data on telecommunication tower levy receipts in Kulon Progo Regency and data on Regional Original Revenue of Kulon Progo Regency from 2015 to 2019.

D. Data

The type of data used for this research is secondary data. Secondary data is data obtained indirectly from the object of research. Researchers obtain ready-made data collected by other parties in various ways or methods, both commercial and non-commercial.

1. Data regarding the general description of Kulon Progo Regency and data on telecommunication towers.

2. Data on the realization of Regional Original Revenue (PAD) of Kulon Progo Regency in the 2015 fiscal year to the 2019 budget year.

3. Data on telecommunication tower revenue realization in Kulon Progo Regency for the 2015 fiscal year to the 2019 fiscal year.

\section{E. Data Collection Techniques}

\section{Interview}

Data collection techniques are carried out directly to obtain information from the source concerned or the authorized department related to the research objectives.

\section{Documentation}

The data collection technique is done by collecting data that comes from the object to be researched. In this research the object to be studied is the Department of Transportation, Communication and Information, Kulon Progo Regency.

\section{F. Data Analysis Techniques}

1 The growth of telecommunication tower levies is used to calculate the growth rate of telecommunication tower charges in Kulon Progo Regency each year during the observation period, namely from 2015 to 2019. The formula used in the analysis of the growth rate of telecommunication tower levies is as follows (Widodo, 1990: 36). [5]

$$
\Delta R P t=\frac{R P t-R P(t-1)}{R P(t-1)} \times 100 \%
$$

Information:

$\Delta \mathrm{RPt}$ : Growth (rate of growth) of telecommunication tower charges

RPt: The amount of telecommunication tower retribution in a certain year

$\mathrm{t}-1$ : The year before the accounting year.

2. Effectiveness analysis is the relationship between the realization of telecommunication tower levy receipts against the telecommunication tower levy receiving target which allows whether the telecommunication tower levy amount is in accordance with the existing target. The amount of effectiveness of retribution can be calculated with the following formula (Halim, 2007: 234) levy receipts

$$
\text { Realization of telecommunication tower }
$$

Effectiveness $\mathrm{X} 100 \%$

Telecommunication tower levy receiving target

If the results of the calculation of the effectiveness of telecommunication tower charges produce a figure / percentage close to $100 \%$, then the telecommunication tower levy will be more effective, and to see the effectiveness of the relevant year with the effectiveness of the previous year.

3. Contribution to calculate the contribution of regional Telecommunication Tower Levy revenue to PAD can be made using the following formula (Daud, 2001: 155).

Receipt

Telecommunication Tower Retribution

Contribution $\mathrm{X} 100 \%$ 
With this analysis, we will get how much contribution the telecommunication tower levies contribute to local revenue (PAD) in Kulon Progo Regency. By comparing the results of the analysis from year to year for five years, the analysis results will fluctuate from these contributions and it will be known that the largest and smallest contributions from year to year. So it can be seen how much the telecommunication tower retribution contributes to the Regional Original Revenue of Kulon Progo Regency.

4. Development of Telecommunication Tower Levies on PAD The development of telecommunication tower levies on Kulon Progo Regency Regional Original Revenue in the 2015 fiscal year to 2019 fiscal year, is carried out using the Trend forecasting method

Trend Least Square.

$Y^{\prime}=a+b x$

$\mathrm{Y}{ }^{\prime}=$ the projected value (acceptance) of telecommunication tower levies

$\mathrm{X}=$ Time interval (years)

$a=a$ constant that will show the value of $Y$ if $X=0$

$\mathrm{b}=$ the amount of change in $\mathrm{Y}$ value of each change in a unit X

$$
\mathrm{a}=\frac{\sum \mathrm{Y}}{\mathrm{N}} \quad \mathrm{b}=\frac{\sum \mathrm{XY}}{\sum \mathrm{X} 2}
$$

$\sum \mathrm{Y}=$ Total telecommunication tower levy received

$\mathrm{N}=$ Amount of data

$\sum X Y=$ Total levy received multiplied by the time interval

$\sum \mathrm{X} 2=$ Total number of time intervals squared

If the equation $Y^{\prime}=a+b X$ has been obtained, then $a$ hypothesis is tested to determine whether the value of $b$ is significant or not.

\section{RESULTS AND DISCUSSION}

\section{A. Analysis and Discussion \\ 1. Description of Data}

This research was conducted at Dishubkominfo Kabupatem Kulon Progo to analyze the amount of contribution of telecommunication tower levy receipts in the 2015 to 2019 budget year. The following is the clarification and calculation of data regarding the amount of the budget and the realization of telecommunication tower levy receipts in Kulon Progo Regency from 2015 to the year 2019
The presentation of and regarding the budget and realization of telecommunication tower charges in the 2015 to 2019 fiscal year is useful to determine the contribution of telecommunication tower levies to the Regional Original Revenue of Kulon Progo Regency from 2015 to 2019 which is one of the problem formulations in this study.

Table IV.1 Difference in Budget and Realization of Telecommunication Tower Retribution Revenue from Kuon Progo Regency 2015-2019

\begin{tabular}{|l|l|l|l|l|}
\hline NO & TAHUN & $\begin{array}{l}\text { ANGGARAN } \\
(\mathrm{RP})\end{array}$ & $\begin{array}{l}\text { REALISASI } \\
(\mathrm{RP})\end{array}$ & $\begin{array}{l}\text { SELISIH } \\
(\mathrm{RP})\end{array}$ \\
\hline 1 & 2015 & 615.295 .905 & 597.981 .423 & 17.314 .482 \\
\hline 2 & 2016 & 615.295 .905 & 664.595 .892 & 49.299 .987 \\
\hline 3 & 2017 & 635.598 .340 & 726.928 .418 & 91.330 .078 \\
\hline 4 & 2018 & 665.742 .869 & 789.260 .943 & 123.518 .074 \\
\hline 5 & 2019 & 744.186 .905 & 818.576 .408 & 74.389 .503 \\
\hline
\end{tabular}

source: Dishubkominfo Kab. Kulonprogo

From the table above, it can be seen that the revenue from telecommunication tower fees budgeted by the Kulon Progo Regency Government is getting bigger every year, starting from 2015 and 2016 amounting to Rp. $615,295,905$ to Rp. $635,598,340$ in 2017 and Rp. $665,742,869$ in 2017 and. 2018, then in 2019 it will be IDR $744,186,905$. In the realization table, it can also be seen that the telecommunication tower levy receipts in Kulon Progo Regency each year exceed the target, except in 2015 which was less than Rp. 17,314,482 of the stipulated budget of Rp. 615,295,905.

\section{Telecommunication Tower Retribution Growth}

The formula used in the analysis of the growth rate of telecommunications tower levies is as follows:

Table IV.2 Growth of Telecommunication Tower Levies in Kulon Progo Regency 2015 to 2019

\begin{tabular}{|l|l|l|l|l|}
\hline NO & TAHUN & $\begin{array}{l}\text { REALISASI } \\
(\mathrm{RP})\end{array}$ & $\begin{array}{l}\text { PERTUMBUHAN } \\
(\mathrm{RP})\end{array}$ & $\begin{array}{l}\text { PORSENTA } \\
\text { SI }\end{array}$ \\
\hline 1 & 2015 & 597.981 .423 & & - \\
\hline 2 & 2016 & 664.595 .892 & 66.614 .469 & $11 \%$ \\
\hline 3 & 2017 & 726.928 .418 & 62.332 .526 & $9 \%$ \\
\hline 4 & 2018 & 789.260 .943 & 62.332 .525 & $9 \%$ \\
\hline 5 & 2019 & 818.576 .408 & 29.315 .465 & $4 \%$ \\
\hline
\end{tabular}

Source: data processing results

From the table above, it can be seen that the growth of telecommunication tower levies in 2019 has no growth because the first levies were collected in 2015, in 2016 amounting to Rp. $66,614,469$ or $11 \%$ increase from 2015. In 2017 the growth was Rp. $62,332,526$ or $9 \%$ increase from 2016, in 2018 it had the same growth rate as 2017 , namely Rp. $62,332,526$ or $9 \%$ an increase from 2017. In 2019 the growth rate decreased from the previous year of IDR $29,315,465$ or $4 \%$ increase from 2018. This decrease was due to differences in the calculation method for obtaining the levy value that was billed from the previous year, but it was seen in the amount of revenue. always increasing.

3. Contribution of telecommunication tower retribution to the Local Government Revenue of Kulon Progo Regency in the 2015 to 2019 fiscal year 
One of the sources of PAD is derived from local taxes, one source of regional taxes itself comes from levies for telecommunications towers which are an important part of supporting Regional Original Revenue in providing a significant contribution to regional revenue. This PAD source is used to finance the implementation and regional development of Kulon Progo Regency.

This study aims to determine the amount of contribution of telecommunication tower retribution which is a component of Kulon Progo Regency Regional Original Revenue in the 2015 to 2019 fiscal year.

Analysis Formulas

Telecommunication Tower Retribution

Receipt

Contribution X $100 \%$

Total PAD

Table IV.3 Analysis of Telecommunication Tower Retribution Contribution in Kulon Progo Regency

\begin{tabular}{|l|l|l|l|l|}
\hline No & Tahun & $\begin{array}{l}\text { Penerimaan PAD } \\
\text { (Rp) }\end{array}$ & $\begin{array}{l}\text { Penerimaan } \\
\text { retribusi } \\
\text { menara } \\
\text { telekomunikasi } \\
(\mathrm{Rp})\end{array}$ & $\begin{array}{l}\text { Porsentase } \\
\mathrm{E}=(\mathrm{c} / \mathrm{d}) \mathrm{x} \\
100 \%\end{array}$ \\
\hline $\mathrm{a}$ & $\mathrm{b}$ & $\mathrm{c}$ & $\mathrm{d}$ & $\mathrm{e}$ \\
\hline 1 & 2015 & 53.752 .293 .431 & 597.981 .423 & 1,11 \\
\hline 2 & 2016 & 54.293 .140 .915 & 664.595 .892 & 1,22 \\
\hline 3 & 2017 & 95.991 .512 .851 & 726.928 .418 & 0,76 \\
\hline 4 & 2018 & 158.623 .927 .339 & 789.260 .943 & 0,50 \\
\hline 5 & 2019 & 187.802 .916 .833 & 818.576 .408 & 0,44 \\
\hline
\end{tabular}

Source: data processing results

From table IV.3 above, it can be seen that from 2015 to 2019, telecommunication tower charges have always contributed to Kulon Progo Regency's Original Revenue, namely in 2015 of $1.1 \%$, in 2016 of $0.69 \%$, in

2017 amounted to $0.76 \%$, in 2018 it was $0.50 \%$ and in 2019 it was $0.44 \%$. Although the contribution of telecommunication tower levies is not very large and decreases every year, if seen from the budget target each year it always exceeds the budget target, this is because telecommunication tower retribution receipts are received only once a year and the frequency of retribution receipts is not as much as the object of retribution another year. The absence of increasing the number of telecommunication towers in Kulon Progo Regency is also the reason why the budget target cannot be increased significantly while the budget target is always increased.

4. The Effectiveness of Telecommunication Towers on PAD Kulon Progo Regency in 2015 to 2019

The effectiveness of receiving telecommunication tower charges can be calculated using the formula: receipts

Realization of telecommunication tower levy

Effectiveness x $100 \%$

Telecommunication tower levy receiving target

From the formula above so that the calculation can be as follows:

Table IV.4 Calculation of Effectiveness of Telecommunication Tower Retribution Receipt

\begin{tabular}{|l|l|l|l|l|}
\hline NO & TAHUN & $\begin{array}{l}\text { ANGGARAN } \\
(\text { RP) }\end{array}$ & $\begin{array}{l}\text { REALISASI } \\
\text { (RP) }\end{array}$ & $\begin{array}{l}\text { EFEKTIVITAS } \\
\text { (RP) }\end{array}$ \\
\hline 1 & 2015 & 615.295 .905 & 597.981 .423 & 97,19 \\
\hline 2 & 2016 & 615.295 .905 & 664.595 .892 & 108,01 \\
\hline 3 & 2017 & 635.598 .340 & 726.928 .418 & 114,37 \\
\hline 4 & 2018 & 665.742 .869 & 789.260 .943 & 118,55 \\
\hline 5 & 2019 & 744.186 .905 & 818.576 .408 & 110,00 \\
\hline
\end{tabular}

source: Dishubkominfo Kab. Kulonprogo (processed)

From the table above, it can be seen that in 2015 the effectiveness of revenue was $97.19 \%$, then in 2016 it increased to $108.01 \%$ and in 2017 it was $114.37 \%$. In 2018 it rose again to $118.55 \%$ and decreased to $110.0 \%$ in 2019 but with a value above $100 \%$. The effectiveness of telecommunication tower levy receipts is increasing every year and has a value close to $100 \%$ or even more than $100 \%$, this indicates that the effectiveness of receiving telecommunication tower charges in Kulon Progo Regency in 2015 to 2019 is very good.

5. Development of Telecommunication Tower Contribution to Kulon Progo Regency PAD.

If it is seen from the calculation that the receipt of telecommunication tower charges always increases every year, but if it is seen that the contribution has decreased, it is necessary to prove it by calculating using Trend Least Square Analysis.

$Y^{\prime}=a+b X$

$\mathrm{Y}$ ' $=$ the projected value (acceptance) of telecommunication tower levies

$\mathrm{X} .=$ Time interval (years)

$\mathrm{a}=\mathrm{a}$ constant which will show the value of $\mathrm{Y}$ if $\mathrm{X}=0$

$\mathrm{b}=$ the amount of change in $\mathrm{Y}$ value of each change in a unit X

1. $\sum Y=$ Amount of telecommunication tower levy received

2. $\mathrm{N}=$ Amount of data

3. $\sum X Y=$ Amount of levy received multiplied by the time interval

4. $\sum X^{2}=$ Number of time intervals squared 
Table IV.5 Calculation of trend square

Calculation of Telecommunication Tower Retribution Receipt

\begin{tabular}{|l|l|l|l|l|}
\hline Tahun & X & Y & Xy & $X^{2}$ \\
\hline 2015 & -2 & 597.981 .423 & -1.195 .962 .846 & 4 \\
\hline 2016 & -1 & 664.595 .892 & -664.595 .892 & 1 \\
\hline 2017 & 0 & 726.928 .418 & - & 0 \\
\hline 2018 & 1 & 789.260 .943 & 789.260 .943 & 1 \\
\hline 2019 & 2 & 818.576 .408 & 1.637 .152 .816 & 4 \\
\hline Jumlah & 0 & 2.334 .765 .769 & 565.855 .021 & 10 \\
\hline
\end{tabular}

Source: data processing results

$\begin{array}{clc}\mathrm{a}=\sum_{\mathrm{N}} \mathrm{Y} & \mathrm{b}=\sum \mathrm{XY} & \\ \mathrm{i \textrm {X } ^ { 2 }} & 565.855 .021 \\ 5 & \mathrm{~b}= & 10 \\ \mathrm{a}=466.334 .765 .769 & & 56.585 .502\end{array}$

Source: data processing results

From the table above, then look for the value of the equation

$\mathrm{Y}=\mathrm{a}+\mathrm{bx}$

Table. IV.6 Calculation of Y Trend

\begin{tabular}{|l|l|}
\hline 2015 & $\begin{array}{l}\mathrm{Y}^{\prime}=466.953 .154+56.585 .502(-2) \\
=353.782 .150\end{array}$ \\
\hline 2016 & $\begin{array}{l}\mathrm{Y}^{\prime}=466.953 .154+56.585 .502(-1) \\
=410.367 .652\end{array}$ \\
\hline 2017 & $\begin{array}{l}\mathrm{Y}^{\prime}=466.953 .154+56.585 .502(0) \\
=466.953 .154\end{array}$ \\
\hline 2018 & $\begin{array}{l}\mathrm{Y}^{\prime}=466.953 .154+56.585 .502(1) \\
=523.538 .656\end{array}$ \\
\hline 2019 & $\begin{array}{l}\mathrm{Y}^{\prime}=466.953 .154+56.585 .502(2) \\
=580.124 .158\end{array}$ \\
\hline
\end{tabular}

Table IV.7 Calculation of $\mathrm{Y}$ trend of telecommunication tower charges

\begin{tabular}{|l|l|l|l|l|}
\hline Tahun & $\mathrm{X}$ & $\mathrm{Y}$ & $\mathrm{Xy}$ & $\mathrm{X}^{2}$ \\
\hline 2015 & -2 & 597.981 .423 & -1.195 .962 .846 & 4 \\
\hline 2016 & -1 & 664.595 .892 & -664.595 .892 & 1 \\
\hline 2017 & 0 & 726.928 .418 & - & 0 \\
\hline 2018 & 1 & 789.260 .943 & 789.260 .943 & 1 \\
\hline 2019 & 2 & 818.576 .408 & 1.637 .152 .816 & 4 \\
\hline Jumlah & 0 & 2.334 .765 .769 & 565.855 .021 & 10 \\
\hline
\end{tabular}

Source: data processing results

To find out whether the "b" value is significant or not, it is necessary to do the " $t$ " test at the 5\% real level. The hypothesis and calculation are as follows:

1. Ho accepted $=$ there is no significant development of telecommunication tower levy receipts in Kulon rogo Regency from 2015 to 2019

2. Ho was rejected there were significant developments in the reception of telecommunication tower charges in Kulon Progo Regency from 2015 to 2019

$3 . \mathrm{Y}=466,953,154+56,585,502(\mathrm{x})$
4. Real rate of $5 \%(0.05)$ The table "t" used is $t 0.025$ Degrees of freedom n-1 then $5-1=4$ So that the table value is 2.77

5. Calculation of the "t" test

${ }^{\text {thitung }}=\quad \underline{\mathrm{b}}_{\mathrm{B}}$

Information:

$\mathrm{b}=$ change in variable $(\mathrm{y})$ per year periodically

$\mathrm{Sb}=$ Standard Error Coefficient

\begin{tabular}{|l|l|l|l|l|l|l|l|}
\hline TAHUN & $Y$ & $X$ & $Y^{\prime}$ & $\left(Y-Y^{\prime}\right)$ & $\left(Y-Y^{\prime}\right)^{2}$ & $(X-X)$ & $(X-X)^{2}$ \\
\hline 2015 & 597.981 .423 & & 353.782 .150 & 244.199 .274 & 59.633 .285 .177 .927 .800 & & 4 \\
\hline 2016 & 664.595 .892 & & 410.367 .652 & 254.228 .240 & 64.631 .998 .216 .880 .200 & & 1 \\
\hline 2017 & 726.928 .418 & & 466.953 .154 & 259.975 .264 & 67.587 .137 .787 .879 .600 & & 0 \\
\hline 2018 & 789.260 .943 & & 523.538 .656 & 265.722 .287 & 70.608 .333 .914 .799 .300 & & 1 \\
\hline 2019 & 818.576 .408 & & 580.124 .158 & 238.452 .250 & 56.859 .475 .577 .753 .000 & & 4 \\
\hline Jumlah & 2.334 .765 .769 & & 2.334 .765 .769 & 1.262 .577 .315 & 319.320 .230 .675 .240 .000 & & 10 \\
\hline
\end{tabular}

Table V.8 calculation of $\mathrm{t}$ count

Source: Results of data processing

The Standard Error Coefficient formula is:<smiles>[X]C1CCCC1</smiles>

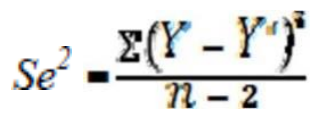

Where $\mathrm{Se} 2$ is obtained by the formula:

$\mathrm{Se}^{2}=\underline{319 \cdot 320 \cdot 230 \cdot 675 \cdot 240 \cdot 000}$

$$
5-2
$$

$\mathrm{Se}^{2}=\underline{319 \cdot 320 \cdot 230 \cdot 675 \cdot 240 \cdot 000}$

$\mathrm{Se}^{2}=106.440 .076 .891 .747 .000$

than $\mathrm{Sb} 2=\underset{\Sigma(X}{(X)} \frac{S e^{2}}{{ }^{2}}$

$\mathrm{Sb}^{2}=106.440 .076 .891 .747 .000$

10

$\mathrm{Sb}^{2}=106.440 .076 .891 .747 .00$

$\mathrm{Sb}=\sqrt{ } 106.440 .076 .891 .747 .00$ 
$\mathrm{Sb}=103.169 .800$

than $\mathrm{t}$ hitung $=\underline{\mathrm{b}}$

SB

$$
\begin{aligned}
= & \underline{56.585 \cdot 502} \\
& 103 \cdot 169 \cdot 800 \\
= & 0,55
\end{aligned}
$$

6. The area of acceptance of Ho and rejection of Ho

Figure V.5 Figure acceptance and rejection of Ho

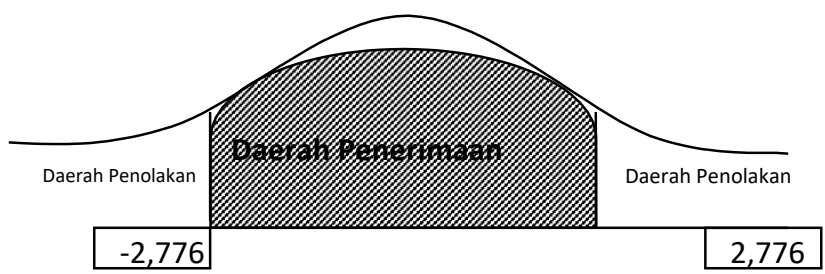

Ho is accepted because $t$ count is smaller than t table, which is $0.55<2.776$

7. The conclusion that Ho is accepted means that there is no significant development towards the increase in telecommunication tower levy receipts in Kulon Progo Regency from 2015 to 2019.

8. Predictions of telecommunication tower levy receipts

\begin{tabular}{|c|c|}
\hline 2015 & $\begin{array}{l}Y^{\prime}=466.953 .154+56.585 .502(-2) \\
353.782 .150\end{array}$ \\
\hline 2016 & $\begin{array}{l}Y^{\prime}=466.953 .154+56.585 .502(-1) \\
410.367 .652\end{array}$ \\
\hline 2017 & $\begin{array}{l}Y^{\prime}=466.953 .154+56.585 .502(0) \\
466.953 .154\end{array}$ \\
\hline 2018 & $\begin{array}{l}Y^{\prime}=466.953 .154+56.585 .502(1) \\
523.538 .656\end{array}$ \\
\hline 2019 & $\begin{array}{l}Y^{\prime}=466.953 .154+56.585 .502(2) \\
580.124 .158\end{array}$ \\
\hline 2020 & $\begin{array}{l}Y^{\prime}=466.953 .154+56.585 .502(3) \\
636.709 .660\end{array}$ \\
\hline 2021 & $\begin{array}{l}Y^{\prime}=466.953 .154+56.585 .502(4) \\
693.295 .162\end{array}$ \\
\hline 2022 & $\begin{array}{l}Y^{\prime}=466.953 .154+56.585 .502(5) \\
749.880 .664\end{array}$ \\
\hline 2023 & $\begin{array}{l}Y^{\prime}=466.953 .154+56.585 .502(6) \\
806.466 .166\end{array}$ \\
\hline 2024 & $\begin{array}{l}Y^{\prime}=466.953 .154+56.585 .502(7) \\
863.051 .668\end{array}$ \\
\hline
\end{tabular}
in 2020 to 2024

By using the equation of the least square

From the table above, it can be seen that the forecasting of telecommunication tower levy receipts will always increase every year, in 2020 it is predicted to be $\mathrm{Rp}$. 636,709,660, then increased to Rp. 693,295,162 in 2021. In 2022 it becomes Rp. 749,880,664, and in 2023 it will increase to Rp. 806,466,166 then in 2024 it becomes Rp. $863,051,668$. In forecasting telecommunication tower levy receipts, it can be seen that telecommunication tower levy receipts can be expected to contribute to the Regional Original Revenue in Kulon Progo Regency even though the amount of increase every year is not conspicuous and is not always correct with forecasting because there are problems or obstacles in the collection and regulations governing telecommunication towers. in Kulon Progo Regency.

Receiving telecommunication tower levies in its management if done optimally by looking at the development of other technologies in communication services to the community such as fiber optic etc., it will provide a useful contribution in the development of Kulon Progo Regency.

B. Inhibiting factors faced by the Department of Transportation, Communication and Information, Kulon

\begin{tabular}{|c|c|c|}
\hline No & Resistance & Settlement / Optimization Efforts \\
\hline 1 & $\begin{array}{l}\text { Companies that are required to } \\
\text { pay levies do not pay levies } \\
\text { orderly } \\
\qquad \begin{array}{l}\text { There is a request for } \\
\text { retribution relief from } \\
\text { mandatory retribution }\end{array}\end{array}$ & $\begin{array}{l}\text { a. Issuing local tax bills } \\
\text { b. Carry out a collection of levies by } \\
\text { issuing a warning letter if the levy is not } \\
\text { paid off } \\
\text { c. Do billing by visiting companies that } \\
\text { do not pay retribution directly } \\
\text { d. Coordination with teams from related } \\
\text { agencies involved in the supervision and } \\
\text { control of telecommunications towers in } \\
\text { Kulon Progo Regency } \\
\text { a. Coordinating with companies that are } \\
\text { robliged to retribution } \\
\text { b. Coordinating with the DPPKA Kulon } \\
\text { Progo Regency and the Kulon Progo } \\
\text { Regent }\end{array}$ \\
\hline 3. & $\begin{array}{l}\text { Tower Cell Plan } \\
\text { Telecommunications in Kulon } \\
\text { Progo Regency does not } \\
\text { accommodate requests for the } \\
\text { construction of } \\
\text { telecommunications towers } \\
\text { because it is outside the cell } \\
\text { plan zone established by the } \\
\text { Kulon Progo Regency } \\
\text { Government }\end{array}$ & $\begin{array}{l}\text { a. Coordination with a team of related } \\
\text { agencies with the supervision and } \\
\text { t control of telecommunications towers } \\
\text { in Kulon Progo Regency } \\
\text { fb. Formulate and publish a new cell } \\
\text { s plan to accommodate the need for new } \\
\text { l tower construction } \\
\text { c. Formulate and issue new regulations } \\
\text { y to accommodate applicants for new } \\
\text { telecommunications towers }\end{array}$ \\
\hline 4. & $\begin{array}{l}\text { There is no regulation that } \\
\text { regulates new cellular } \\
\text { communication services other } \\
\text { than communication towers } \\
\text { such as fiber optic etc. }\end{array}$ & $\begin{array}{l}\text { Formulate new rules governing the } \\
\text { restablishment or construction of new } \\
\text { r communication service facilities other } \\
\text { sthan telecommunications towers }\end{array}$ \\
\hline
\end{tabular}
Progo Regency in the Telecommunication Tower Levy Collection Process from 2015 to 2019

Source: dishubkominfo and interview

\section{CONCLUSIONS AND SUGGESTIONS}

\section{A. Conclusion}

1. The contribution of telecommunication tower levies in Kulon Progo Regency in 2015 to 2019 ranged from $0.44 \%$ to $1.22 \%$, although there was a decrease in its contribution every year, in fact telecommunication tower retribution receipts always increased every year. From the realization of telecommunication tower levy receipts which has increased every year starting from 2015 and 2016 amounting to Rp. $615,295,905$ to Rp. $635,598,340$ 
in 2017 and Rp. 665,742,869 in 2018, then in 2019 to Rp. $744,186,905$.

2. The effectiveness of receiving telecommunications tower fees is increasing every year and has a value that is close to $100 \%$ and even exceeds $100 \%$, this indicates that the effectiveness of receiving telecommunications tower fees in Kulon Progo Regency in 2015 to 2019 is very good.

3. The results of the analysis of the trend of telecommunications tower charges obtained by the equation $\mathrm{Y}=466,953,154+56,585,502(\mathrm{X})$ then found the tcount value of $0.55 \%$. Ho's conclusion is accepted because tcount is smaller than table, which is 0.55 <2.776, which means that there is no significant development towards the increase in telecommunication tower levy receipts in Kulon Progo Regency in 2015 to 2019.

4. The predicted amount of telecommunication tower levy receipts continues to increase every year, in 2020 it is predicted to be Rp. 636,709,660, then increased to Rp. $693,295,162$ in 2021. In 2022 it becomes $\mathrm{Rp}$. $749,880,664$, and in 2023 it will increase to Rp. $806,466,166$ then in 2024 it becomes Rp. 863,051,668. So it can be seen that the revenue from telecommunication tower retribution can be expected to contribute in the Regional Original Revenue for the development of Kulon Progo Regency.

Inhibiting factors faced by the Department of Transportation, Communication and Informatics, Kulon Progo Regency in increasing the reception of telecommunication tower fees, among others, because companies that are required to pay levies are not orderly paying retribution, there is a request for levy relief from mandatory retribution, the Cell Plan for telecommunications towers in Kulon Progo Regency does not accommodate applications for establishment telecommunication tower because it is outside the cell plan zone stipulated by the Kulon Progo Regency Government and there is no regulation that regulates new cellular communication services apart from communication towers such as fiber optic and others. There are several obstacles faced by the Department of Transportation, Communication and Information Technology of Kulon Progo Regency as a telecommunication tower levy collector, making efforts to solve the problem, including issuing local tax bills, collecting levies by issuing a warning letter if not repaying the levy debt, making billing with go directly to companies that do not pay fees, coordinate with teams from related agencies that participate in the supervision and control of telecommunications towers in Kulon Progo Regency, coordinate with companies that are obliged to retain fees, issue new cell plans that accommodate the need for establishing new communication services and issue new regulations accommodating applicants for new telecommunications towers.

\section{B. Research Limitations}

1. The author formulates the contribution of manara telecommunications to Regional Original Revenue with only 5 years of data from 2015 to 2019 .

2. The data used in this study are secondary data (data collected by other parties) and not primary data (data collected by the author himself)

\section{Suggestions}

From the research that has been done, it is found that there are many deficiencies that can affect the running of the withdrawal mechanism and the amount of telecommunication tower levy receipts that have an impact on increasing revenue from PAD. So the authors propose several suggestions in the context of the effectiveness of the collection of telecommunication tower charges in Kulon Progo Regency so as to be able to increase the reception of telecommunication tower charges which in turn will contribute to the increase in Regional Original Revenue in Kulon Progo Regency.

1. The increase in telecommunication tower levy receipts should be maintained, the decrease in the contribution of telecommunication tower charges Regional Original Revenue is a concern so that the Kulon Progo Regency Government optimizes the telecommunication tower retribution revenue. So that regional revenue that is useful for development can be a source of income that can be used to finance the implementation of government and development in Kulon Progo Regency.

2. The status of telecommunication towers in terms of communication services that are included as public services that should be provided by the regional government, due to their inability to be provided by the private sector. The status of business services should be because the private sector takes big profits, because it is changed to the status of business services, the government can collect larger fees which have an effect on increasing the amount of retribution revenue so that the contribution of tower fees to Regional Original Revenue increases.

3. Each city / regency government must have an agreement on the collection of levies for telecommunications towers in their area, this agreement includes:

a. Rejection of requests for levy relief by telecommunications tower owners.

b. Take firm action against telecommunication tower owners who do not orderly pay retribution by imposing sanctions

\section{REFERENCES}

1. Hasthoro, H.A., and Sunardi. 2014. Public Governance and Local Government Financial Performance in Indonesia. Proceedings of the 3rd Economics \& Business Research Festival, Faculty of Economics and Business, Satya Wacana Christian University Salatiga, Indonesia. 
2. Rahmawati Widya Putri. Analysis of the Contribution of Parakir Levies on Local Revenue of Malang Regency: research for the 2010 to 2014 fiscal year, and predicting the receipt of parking fees in 2015 to 2019.

3. Christina Ratih Puspa Dewi. Analysis of the Contribution of Hotel and Restaurant Taxes to Local Own Revenue: research for the 2004 to 2008 fiscal years and forecasting the growth of hotel and restaurant taxes on Regional Own-Owned Income in 2009 to 2013 for DIY.

4. Azhar, M.K.S. 2008. Financial Performance Analysis of District / City Government Before and After Regional Autonomy. (Thesis. Masters Program in Accounting, Graduate School, University of North Sumatra, Medan).

5. Bovaird, T., and E. Loffler. 2003. Understanding Public Management and Governance. in Bovaird, T., and E. Loffler. (Eds). Public Management and Governance. London, UK: Routledge.

6. Dwiyanto, A. 2008. Realizing Good Governance through Public Services. Yogyakarta: Gadjah Mada Press.

7. Hasthoro, H.A., and W. Septianto. 2015. The Effect of Financial Conditions on the Performance of Local Government in Indonesia. Proceedings of the 4th Economics \& Business Research Festival, Faculty of Economics and Business, Satya Wacana Christian University Salatiga, Indonesia.

8. Hasthoro, H.A., H. Sarnowo, Nurwiyanta. 2016. The impact of financial condition on public governance among provincial government in Indonesia. Proceeding 1st ICOBAME: International Conferences on Business, Accounting, Management, and Economics, Faculty of Economics \& Business, University of STIKUBANK Semarang, Indonesia.

9. Hill, C.J., and L.E. Lynn Jr. 2004. Governance and Public Management, an Introduction. Journal of Policy Analysis and Management 23 (1): 3-11.

10. Mahmudi. 2010. Public Sector Performance Management. 2nd Edition. Yogyakarta: UPP STIM YKPN.

11. Mimba, N.P.S.H., G.J. Helden, and S. Tillema. 2007. Public Sector Performance Measurement in Developing Countries: A Literature Review and Research Agenda. Journal of Accounting \& Organizational Change 3 (3): 192-208.

12. Osborne, S.P. 2010. The New Public Governance: A Suitable Case for Treatment? in Osborne, S.P. (Ed). The New Public Governance? Emerging Perspectives on the Theory and Practice of Public Governance. London, UK: Routledge.

13. Government Regulation No. 3 of 2007 concerning Reports on Regional Government Administration.

14. Ritonga, I.T., C. Clark, and G. Wickremasinghe. 2012. Assesing Financial Condition of Local Government in Indonesia: An Exploration. Public and Municipal Finance 1 (2): 37-50.

15. Syurmita. 2014. Prediction of Financial Distress for Regional Government of Regency / City in Indonesia. XVII National Accounting Symposium: Banjarmasin, Indonesia.

16. Law of the Republic of Indonesia No. 23/2014 on Regional Government. 